\title{
Withdrawing Provisional Application of Treaties: Has the EU Made a Mistake?
}

\author{
Lorand Bartels
}

\section{Introduction}

It is a common practice, recognized by Article 25 of the Vienna Convention on the Law of Treaties (VCLT), for negotiating parties to a treaty to apply some or all of the provisions of the treaty provisionally prior to the treaty's entry into force. ${ }^{1}$ Sometimes, if the treaty never comes into force, it can operate on the basis of provisional application for many years. The General Agreement on Tariffs and Trade (GATT) is a stand out example. This agreement, signed in 1947, was intended to apply on a provisional basis for only a few years, until the framework International Trade Organization came into force. However, when the GATT failed to gain favour in the US Congress, the ITO was abandoned, and the GATT continued as a provisionally applied agreement until 1995, when it was replaced by the World Trade Organization.

The practice of provisional application presents numerous theoretical and practical difficulties, and the inclusion of Article 25 into the Vienna Convention was not uncontroversial. ${ }^{2}$ One problem is that, the practice can bypass normal democratic controls on the treaty-making process. Some countries guard against this possibility, for example by subjecting provisional application to the same procedures as treaty ratification. ${ }^{3}$ Other legal systems are more flexible. The European Union, for example, expressly authorises the EU Council to

\footnotetext{
* University Senior Lecturer in Law and Fellow of Trinity Hall, University of Cambridge. Research for this note was conducted at the request of the Commonwealth Secretariat.

1 Technically, a negotiating or signatory party only becomes a 'party' to a treaty once it is in force.

2 D. Mathy, 'Article 25' in Oliver Corten and Pierre Klein, The Vienna Conventions on the Law of Treaties: A Commentary (OUP, 2011), Volume I, at 641-2.

3 A. Quast, The Binding Force and Legal Nature of Provisionally Applied Treaties, PhD thesis (University of London, 2010), at 52.
} 
adopt a decision provisionally applying a treaty prior to its entry into force. This final step requires the consent of the European Parliament. ${ }^{4}$

Other problems exist at the international level. It is clear, as held by the arbitral tribunal in Yukos, that provisional application is binding and enforceable, ${ }^{5}$ although the theoretical basis for this is still not certain. ${ }^{6}$ This note considers two other questions, which do not appear to have received scholarly attention, and which have recently presented themselves in a case involving the EU's treaty practices. The first is whether, under Article 25(1) of the Vienna Convention, provisional application must be reciprocal, or whether it can be unilateral. The second concerns the conditions under which provisional application may be withdrawn, and whether Article 25(2), which governs withdrawal, is perhaps too strict in certain cases. In this respect it is worth noting at the outset that, while Article 25(1) might be considered to represent customary international law, doubts have been expressed as to the status of Article 25(2), ${ }^{7}$ although it was cited with approval in Yukos. ${ }^{8}$

\section{The EU's Economic Partnership Agreements}

These two questions have recently arisen in relation to a set of reciprocal free trade agreements, known as interim (and in one case full) Economic Partnership Agreements (EPAs), between the EU and a number of African, Caribbean and Pacific (ACP) states. ${ }^{9}$

The EPAs were designed as reciprocal free trade agreements that were to replace the unilateral trade preferences that were granted by the EU to the ACP states under the Cotonou Agreement. Due to their unilateral nature, these preferences were permitted under WTO law only because of a specific waiver

${ }^{4}$ Article 218 of the Treaty on the Functioning of the European Union, [2008] OJ C 115/49, 9 May 2008.

5 Yukos Universal Limited (Isle of Man) $v$ The Russian Federation, Interim Award on Jurisdiction and Admissibility, 30 November 2009, PCA Case No AA 227, available at <http://www.ita law.com $>$ [last accessed 7 May 2012], para. 388.

6 Article 243(3) and (4) 'apply', as per Article 24(4) VCLT. There is significant academic debate on what the legal force is of this 'application'; the most convincing theory is that there is a collateral agreement to this effect (which may be unwritten): see Quast, supra, note 3, at 190.

7 Mathy, supra, note 2, at 641-2.

8 Yukos, supra, note 5, para. 388.

9 These can be found on the EU's website at <http://eur-lex.europa.eu/en/index.htm> [last accessed 7 May 2012]. For convenience, these will be referred to here as 'EPAs'. 
to this effect. Both the waiver and the preferences were due to expire on 31 December 2007, at which point the EPAs were intended to come into effect. As it turned out, however, the negotiation process took longer than expected, and as the deadline approached the most that could be achieved was a mutual initialling of the EPAs, with signature to follow. This was however a sufficient basis for the EU to adopt a regulation, under which it would continue to grant unilateral preferences from 1 January 2008, until the relevant procedures could be completed. ${ }^{10}$

Naturally, the EU was wary of the possibility that its new regulation might have the effect that the other negotiating parties would not adhere to their side of the bargain. To guard against this risk, the regulation provided for the withdrawal of preferences from a beneficiary, inter alia, if:

ratification of an agreement ... has not taken place within a reasonable period of time such that the entry into force of the agreement is unduly delayed. ${ }^{11}$

As it turned out, after four years 18 of the original 36 negotiating parties had still not taken steps to ratify their respective agreements. Frustrated, on 30 September 2011 the European Commission issued a proposal to withdraw preferences from these beneficiaries by 1 January 2014, unless steps were taken by then to ratify the agreements. ${ }^{12}$ On 13 April 2012, David Martin, Rapporteur of the International Trade Committee of the European Parliament, issued a draft report broadly approving the Commission's proposed resolution, though with a later withdrawal date of 1 January 2016. This resolution, possibly amended, will go forward to a vote by the European Parliament, before being decided also by the EU Council.

It can be seen from this description of events that the question of provisional application arises in an unusual context. In the first place, the application of the EPAs is so far one-sided, with only the EU having taken steps to implement

${ }^{10}$ Council Regulation $1528 / 2007$ of 20 December 2007 applying the arrangements for products originating in certain states that are part of the African, Caribbean and Pacific (ACP) Group of States provided for in agreements establishing, or leading to the establishment of, Economic Partnership Agreements [2007] OJ L 348/1 (31 December 2007).

${ }^{11}$ Article 2(3)(b) of Regulation 1528/2007, ibid.

${ }^{12}$ Commission Proposal to amend Annex I to Council Regulation (EC) No 1528/2007 $\operatorname{COM}(2011) 598$ final. The proposal lists 18 countries: Botswana, Burundi, Cameroon, Comoros, Cote d'Ivoire, Fiji, Ghana, Haiti, Kenya, Lesotho, Mozambique, Namibia, Rwanda, Swaziland, Tanzania, Uganda, Zambia, and Zimbabwe. Zimbabwe has now completed its ratification procedures. 
provisions under the EPAs. Second, the EU is threatening to withdraw this application of the EPAs not-as is usual-because it no longer wishes to be a party to the agreements but rather for precisely the opposite reason: it wishes to put pressure on the other negotiating parties to conclude negotiations and implement their obligations under the agreements. How, then, does this fit into the framework set out in Article 25 of the Vienna Convention?

\section{The EU regulation as an act of provisional application}

The first question is whether the EU's regulation constitutes an act of provisional application within the meaning of Article 25 of the Vienna Convention. Article 25(1) states:

A treaty or a part of a treaty is applied provisionally pending its entry into force if:

(a) the treaty itself so provides; or

(b) the negotiating States have in some other manner so agreed.

The EPAs all contain provisions on their application pending entry into force. Indeed, this is done in a particularly elaborate way. Each of the treaties provides for both 'provisional application' and 'application'. Article 105 of the Interim Economic Partnership Agreement between Southern African Development Community (SADC) and the EU and its Member States is an example. First there are two paragraphs on 'provisional application':

4. Pending entry into force of this Agreement, the European Community and the SADC EPA States agree to apply the provisions of this Agreement which fall within their respective competences ('provisional application'). This may be effected either by provisional application where possible or by ratification of this Agreement.

5. Provisional application shall be notified to the depositary. This Agreement shall be applied provisionally ten days after either the receipt of notification of provisional application from the European Community or of ratification or provisional application from all the SADC EPA States, whichever is the later. 
Next, there is a paragraph on unilateral 'application' before 'provisional application':

6. Notwithstanding paragraph 4, the European Community, the EC Party and SADC EPA States may unilaterally take steps to apply this Agreement, before provisional application, to the extent feasible.

The question then is how these provisions are to be understood in terms of Article 25(1) of the Vienna Convention. It seems relatively straightforward that the treaty provisions on 'provisional application' fall under Article 25(1)(a) of the Vienna Convention. But what about the provision on unilateral 'application'? This is certainly a treaty provision, and therefore potentially within the scope of Article 25(1)(a), but does it concern 'provisional application'? In answering this question, it is perhaps helpful to begin by examining the difference between these two provisions in practice.

As mentioned, the EU adopted a regulation on 1 January 2008 continuing the former unilateral tariff preferences provided until then under the Cotonou Agreement. This regulation purported to be a unilateral 'application' of the EPAs. This can be seen from Recital 4 of the regulation, which makes direct reference to the respective provisions of these agreements:

Whereas ... [t]hose agreements establishing, or leading to the establishment of, Economic Partnership Agreements for which negotiations have been concluded provide that the parties may take steps to apply the agreement, before provisional application on a mutual basis, to the extent feasible. It is appropriate to take action to apply the agreements on the basis of these provisions. ${ }^{13}$

There has subsequently been one case of mutual 'provisional application', following this act of unilateral 'application', namely of the Cariforum-EU EPA. ${ }^{14}$ Interestingly, aside from the obvious fact that one of these acts is mutual, and the other unilateral, from the EU side the two acts are virtually identical. There are some minor changes in rules of origin and rules on the suspension of preferences in cases of fraud, and certain institutions have been established, but otherwise nothing significant has changed.

${ }^{13}$ Council Regulation 1528/2007, supra, note 10.

${ }^{14}$ Notice concerning the provisional application of the CARIFORUM-EC Economic Partnership Agreement [2008] OJ L352/62 (31 December 2008). 
In substantive terms, then, there seems to be no reason why the unilateral 'application' of the EPAs could not be considered a case of 'provisional application' under Article 25(1)- unless Article 25(1) does not recognize unilateral provisional application. This does not, however, appear to be the case. Textually, Article 25 simply refers to the act of provisionally applying a treaty: there is no requirement that such an act be mutual. Indeed, this appears to be uncontroversial. Sir Ian Sinclair, in his classic work The Vienna Convention on the Law of Treaties noted that "there are other instances where some only of the negotiating States may agree to apply the treaty or part of it provisionally pending its entry into force." ${ }^{15}$ A recent example is the 2003 social security agreement between the Netherlands and Romania, which provides that " $t$ ]he Netherlands shall apply Article 4 of this Agreement provisionally from the first day of the second month following the date of signature."16

What, then, of the fact that the EPAs use distinct terminology for each of two types of 'application'? Here, too, there does not appear to be much by way of objection. Certainly, it does not matter that unilateral 'application' is not called 'provisional application': there are numerous treaties that use varying terminology. Examples are the 1949 Air Transport Agreement between Czechoslovakia and Finland, which provided that its provisions 'shall be applied from the date of signature', and the 1947 Air Transport Agreement between Chile and the US, which provided that "[b]oth contracting parties shall undertake to make effective the provisions of this agreement, within their respective administrative powers, from the date on which it is signed." ${ }^{\prime 17}$ Nor is there any other reason to think that unilateral 'application' is special, other than that it is unilateral. If the negotiating parties wished to remove it from the application of the rule reflected in Article 25(1), they should probably have said so.

In sum, everything points to the EU's regulation as an instance of provisional application of the respective EPAs. It does not matter that the provisional application is triggered by one of the parties acting unilaterally, or that it is not called 'provisional application'. But if this is true, then when can the EU's unilateral 'application' of the agreements be terminated?

\footnotetext{
${ }^{15}$ I. Sinclair, The Vienna Convention on the Law of Treaties (Manchester University Press, 1984), at 46. See also A. Mitchie, 'The Provisional Application of Arms Control Treaties', (2005) 10 Journal of Conflict and Security Law 345.

16 This example is in Mitchie, ibid.

17 These examples are found in H. Blix and J. Emerson, The Treaty Maker's Handbook (Oceanea, 1973), at 85.
} 


\section{Termination of provisional application}

This question is dealt with in Article 25(2) VCLT, though admittedly, as mentioned above, this rule may not reflect customary international law. This provision states as follows (with emphasis):

Unless the treaty otherwise provides or the negotiating States have otherwise agreed, the provisional application of a treaty or a part of a treaty with respect to a State shall be terminated if that State notifies the other States between which the treaty is being applied provisionally of its intention not to become a party to the treaty.

The point of this provision is to strike a balance between legal security and flexibility. But the present case points out its limitations. It is clear that the negotiating states have not agreed to the EU's termination of its provisional application of the treaty, and the treaties do not 'otherwise provide' that the EU may terminate its application of the respective treaties. But nor does the EU propose not to become a party to the respective treaties. To the contrary, the EU is now acting in order that the other negotiating states will be persuaded to ratify the agreements as soon as possible.

\section{Consequences}

As such, the EU is now in a dilemma. But there is also a broader question: whether the rule set out in Article 25(2) of the Vienna Convention is too restrictive.

The problem, as this case study illustrates, is that Article 25(2) can lead to a perverse result. As we have seen, it means that a negotiating party that undertakes an obligation, provisionally, in order to encourage other parties to do the same, is then trapped by those obligations unless it wishes to denounce the agreement. This makes no sense in situations in which it wishes the exact opposite, and, moreover, entered into those obligations precisely in order to encourage the ongoing participation of the other negotiating parties in the process.

This does not appear to be a sensible state of affairs, and may even lead to the conclusion that Article 25(2) does not reflect customary international law. On the other hand, if this is true, then perhaps the EU's proposal is valid after all. 